\title{
Analysis of Intra-Urban Mobility of the Elderly in a Medium-Size City in Southwestern Nigeria
}

\author{
Moses Olaniran Olawole \\ Department of Geography, Obafemi Awolowo University, Ile-lfe, Nigeria \\ Email:moolawole@gmail.com, molawole@oauife.edu.ng
}

Doi:10.5901/mjss.2015.v6n3s2p90

Abstract

Studies on mobility of the elderly, in Nigeria, are recent but scanty. This paper explored mobility characteristics and intra-urban trip patterns of the elderly in a traditional city of Southwestern Nigeria. Data for the study were obtained from a multistage survey conducted in 2012. Chi-square and logistic regression were used for data analysis. Findings showed that an average of 3.01 trips was generated daily per elderly, $70.90 \%$ of the elderly lack motorized means of transportation. Occasional trips frequency accounted for $51 \%$ of the visits to six trip destinations. Daily trips frequency accounted for $19.26 \%$ of the trips. The results of the study validate previous findings regarding the relevant of taxis and walking as mode choices of the elderly in the country. Logistic regression analyses found that: (1) while gender, education and monthly income are significant determinants of walking as mode choice to work places, the amount of variations in the mode choice explained by the variables was relatively low: (2) there exits negative relationship between the choice of walking as modal choice and travel distance; and transport cost to work places. The paper suggests improvement in the condition of access roads within the city among others.

Keywords: Elderly, intra-urban, trip, commuting, mode, choice, Nigeria

\section{Introduction}

The proportion of persons 60 years and over is growing faster than any other age group in developed countries. The growing trend in population of the elderly is gradually manifesting in the developing countries. In Nigeria, there were 4,598,114 persons aged 60 and above in Nigeria in 1991 and by the year 2060, the country is expected to have the largest older population in sub-Saharan Africa, with over 12 million people 60 years and over (NPC, 2003 ; Velkoff and Kowal, 2006, Togonu-Bickersteth, 2014).

The future increase in older people population will not only place new and growing demands on the economy, but also on transport infrastructure and services. Good access to transport infrastructure and services is necessary for the enhancement of the quality of life of the elderly. It enhances their participation in activities such as grocery shopping, withdraw of pension payment from a bank, visit to a doctor, post office, visit to a library or to attend a religious service, to remain engage with their communities and to retain their independence ( Banister and Bowling 2004; Metz 2003; Metz 2000; Engels and Liu, 2011).

However, in Nigeria, ageing related transportation and mobility issues have a low priority in national policies and programmes. This is reflected in the lack of National Policy on the care and welfare of elderly and total absence of transport policy on mobility issues concerning the elderly (Adebowale et al., 2012; Ipingbemi, 2010; Ajomale, 2007). This can be attributed to the inadequate knowledge base in the country, on mobility issues of the elderly. This gap thus strengthens the need to further our understanding of trip patterns of the elderly within an urban centre and also to examine the determinants of their modal choice. Specific objectives of this study are to examine intra-urban trip characteristics, determine gender variation in modal choice and identify the determinants of mode choice of the elderly in llesa, a medium-size city, in Southwestern Nigeria

\section{Literature Review}

Past studies have found that the travel behavior and activity patterns of the elderly are different from those of the general population especially in developed countries. An important component of these studies is the focused on elderly demand for transportation services ( Rosenbloom, 2004; Kim and Ulfarsson, 2004). For instance, a study by Kim and Ulfarsson (2004) showed that the elderly are more likely to use the local transit system if they live within five blocks of a bus stop and are less likely to use the transit system when going to shopping centers. Similarly, Schmocker et al., (2008) also 
found that taxis were mostly used by the elderly for homebound trips than for trips to shopping centers due to the need to carry purchases home.

Hjorthol et al., (2010) examined the activity and travel patterns of different groups of older people in Denmark, Norway and Sweden. Using data from the National Travel Surveys of the three countries across a period of 20 years, their study showed a significant period effect in car ownership and use among older people in Denmark, Norway and Sweden with a clear increase during the past 20 years.

A variety of studies have also examined mobility issues of the elderly such as trip distance, mode choice, trip frequency and trip chaining, using different modeling techniques ( Engels and Liu, 2013; Van den Berg et al., 2011; Schmöcker et al., 2008; Golob and Hensher, 2007; Páez et al., 2006; Stern , 1993). For example, Schmöcker et al., (2008) estimated a model for the total number of trips of elderly and disabled people, as well as different models for different trip purposes (working, shopping, business, and recreation). They found that increasing age and walking difficulties result in fewer trips. Household structures, ethnic background, income, access to a car and taxi or public transport car ownership were found to have an effect on trip-making frequency as well. High education and being married resulted in more trips.

$\mathrm{Hu}$, et al., (2013), in a study of travel behaviour of the in Changchun, China compared travel pattern and difference between elderly people and other age groups in the aspects of travel mode share, trip purpose, average trip rates and daily trip frequency. They revealed that older people trip purposes include more of trips to shopping, entertainment and physical training, and visitation to friends/ doctors than work trips. Their study further shows that older men trip rates are higher than women by a small margin of 0.108 trips per day. In terms of trip frequency, the study revealed that older men have a higher trip frequency in work, entertainment and physical training trips than women, while, older women have a higher trip frequency in shopping than men. In addition, the study confirmed that walking and public transport are the dominant mode shares of elderly and that the choice of personal car as mode choice is very low due to the low level of ownership of private car among older men and women in Changchun and in China as a whole.

Porter et al., (2013) examined transport and mobility constraints and impact on health and livelihood of older people in 10 settlements in Kibaha district, Tanzania, using qualitative and quantitative data. The study revealed that transport, health, livelihood and well-being are interconnected. Transport was observed to constitute major hurdle for many older people particularly for their daily access to domestic water and fuel sources and in accessing health care services.

In recent time, a number of studies have attempted to examine mobility of the elderly in Nigeria. For instance, Ipingbemi (2010), using data from a survey of 264 elderly, examined travel characteristics and mobility crisis of the elderly in Ibadan Metropolis. The study showed that work and health related trips accounted for $31.8 \%$ and $27.1 \%$ of the journey purpose, while the use of bus and walking respectively accounted for 30\%and $29.6 \%$ of the modal split. The study identified vehicle design, long access and waiting time as well as poor facilities at the terminals as constraints to the effective mobility of the elderly. Olawole and Aloba (2014) examined commuting patterns, quality of transport services and the satisfaction level of elderly with transport services in Osogbo Southwestern Nigeria. Their study revealed among others a high level of dissatisfaction with transport services among the sampled elderly.

The two studies: Ipingbemi (2010) and Olawole and Aloba (2014) have helped to break new ground in understanding elderly mobility. However, from research and policy advocacy stand point, the studies are experimental in nature and therefore, insufficient to make much impact on the formulation of national transport policy for the elderly in the country or to support any contentions about the possible transportation impacts of ageing population.

\section{Study Area}

The study was conducted in llesa, one the main towns in Osun State, Nigeria. llesa is located between latitude 7034' $30^{\prime \prime} \mathrm{N}$ and latitude $7^{0} 41^{\prime} 00^{\prime \prime} \mathrm{N}$ and between longitude 4042'00" and longitude 4048'00"E. The study area consists of llesa West and llesa East Local Government Areas (LGAs) and it share boundaries with Obokun LGA in the North, Oriade LGA in the west. Atakunmosa East and West LGAs share the southern boundary, while Atakunmosa West LGA shares the eastern boundary of the study area (Figure 1).

Transport services in llesa are provided by individuals. There are no state owned intra-city transport services. Taxis and motorcycles are the major transport services provided by commercial operators, while mini-buses services are available in few areas of the town (see Adetunji, 2013). 


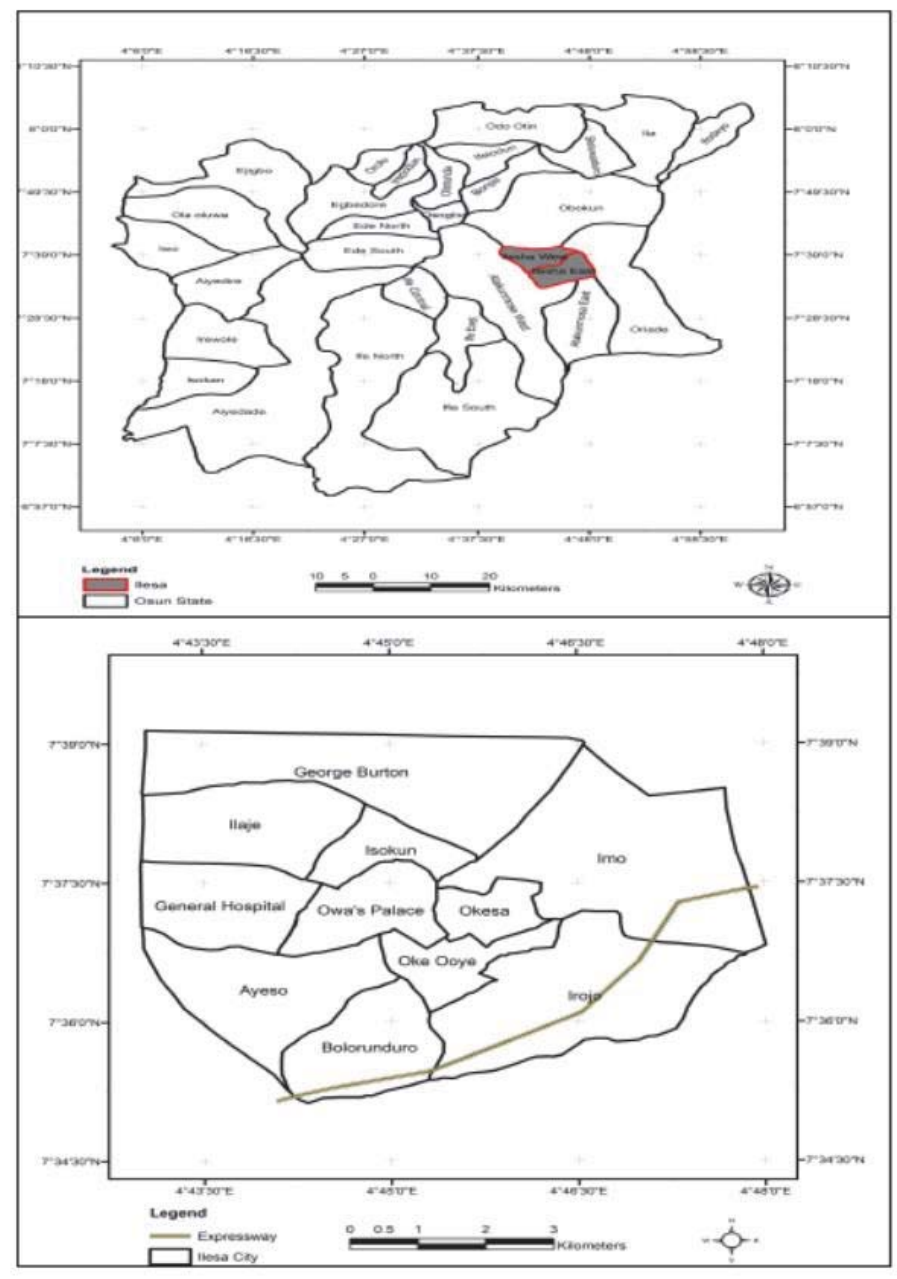

Figure 1. Osun state and llesa

\section{Material and Methods}

Data for the study were obtained from a travel survey conducted in llesa, Southwestern Nigeria in 2012. Data were collected through the administration of questionnaires and field observations. Multistage sampling procedure was used to select elderly for questionnaire administration. For the study to be truly representative of the city and for the purpose of objective data collection and analysis, the city was divided into eleven districts or Traffic Analysis Zones (TAZ): Owa's palace, Ilaje, Imo, Okesa, Irojo, Bolorunduro, Ayeso, General Hospital, George Burton, Oke Ooye and Isokun zones (See Adetunji, 2013, Olawole and Aloba, 2014). Within each zone, 10\% of the streets were randomly selected from a compiled list. Selection of houses was by simple random sampling technique. However, the selection was made in such a way that all the houses with elderly living in them were represented. An elderly was selected for questionnaire administration, from the houses in each of the zone using lottery method. In total 396 elderly were interviewed. Overall, 378 (95.45\%) questionnaires were completed accurately and were used in the analysis (Table 1). Interviews were conducted, face to face, with the sampled elderly by the researcher and trained research assistants.

Chi-square tests were used to determine whether walking as mode choice was significant by gender and by age groups. Logistic regression, a multivariate regression technique, was also used to analyse factors associated with walking as modal choice of the elderly. The objective for applying the model was to determine the most significant factors accounting for respondents' choice of walk as main mode of travel.

The Logistic regression model is a generalisation of the binary logit model and is often used to estimate the relationship between binary or ordinal responses and a set of numerical and categorical explanatory variables. In the analysis, walking as mode choice is the dependent variable and was coded (1), other modes were group together and assigned the value (0). The independent variables included in the model consist of socio-economic attributes of the 
respondents (gender, age, marital status education, income) and trip attributes (ownership of transport means, trip frequency, travel distance, travel time and travel cost).

This study employed statistical software, SPSS, to estimate logistic regression models. The basic formula for logistic regression equation is:

$$
\operatorname{logit}[p(x)]=\log \left\lceil\frac{p(x)}{1-p(x)}\right\rceil=a+b_{1} x_{1}+b_{2} x_{2}+b_{3} x_{3} \cdots
$$

Simple rearrangements of the above formula give the expression for the calculation of $p$ as shown below:

$$
p=\frac{\exp ^{\left(\mathrm{a}+\mathrm{b}_{1} \mathrm{x}_{1}+\mathrm{b}_{2} \mathrm{x}_{2}+\mathrm{b}_{3} \mathrm{x}_{3} \ldots\right)}}{1+\exp ^{\left(\mathrm{a}+\mathrm{b}_{1} \mathrm{x}_{1}+\mathrm{b}_{2} \mathrm{x}_{2}+\mathrm{b}_{3} \mathrm{x}_{3} \ldots\right)}}
$$

Where:

$p=$ the probability that a case is in a particular category,

exp $=$ the base of natural logarithms (approx 2.72),

$a=$ the constant of the equation and,

$b=$ the coefficient of the predictor variables.

To test the strength and reliability of the models, both the Hosmer and Lemeshow test and Nagelkerke R square values are reported. The Hosmer and Lemeshow test examines whether the model for the predicted probabilities is a good match; in this test a large $p$-value ( $p>0.05$ ) is required (Lemeshow and Hosmer 1982, Larsen, et al, 2012). The Nagelkerke R-square value attempts to explain the proportion of variance explained by logistic regression (Nagelkerke, 1991).

Table 1: Distribution of samples based on Traffic Analysis Zones

\begin{tabular}{cc}
\hline Traffic Analysis Zone & Sample \\
\hline Owa's Palace & 38 \\
Ilaje & 43 \\
Imo & 35 \\
Okesa & 37 \\
Irojo & 33 \\
Bolorunduro & 30 \\
Ayeso & 22 \\
General Hospital Area & 44 \\
George Botton/lbala & 20 \\
Oke Ooye & 48 \\
Isokun & 28 \\
Total & 378 \\
\hline
\end{tabular}

\section{Results}

The results of this study are presented under the following subheading: sample characteristics, trip pattern/characteristics and Logistic Regression Model

\subsection{Sample Characteristics}

The socio-economic characteristics of respondents are presented in Table 2. The table shows that the sample consisted of $62.40 \%$ male and $37.60 \%$ female. About $23.3 \%$ of the respondents are within the age range 60 to 64 years. Respondents in the age range 65 to 69 years were $28 \%$ and $22.0 \%$ were between the ages of 70 and 74 years. Elderly respondents aged 75 years and above accounted for 26.7 percent. The majority (73.28\%) of respondents were married as shown in Table 2. The proportion of the respondents that are widowed is 24.34 percent, few (1.32\%) of the respondents were not married, while $1.06 \%$ were divorced. Educational information of the respondents showed that $29.9 \%$ had no formal education, 34.2\%were educated up to tertiary levels, while those with primary and secondary education are $19 \%$ and $16.9 \%$ respectively. Majority (59.0\%) of the elderly were not employed. Majority (70.90\%) of the sampled elderly had no access to personal means of transport, while $29.10 \%$ of the respondents had personal transport means (Figure 2). 


\subsection{Trip Patterns}

This section details the trip patterns of the respondents with emphasis on trip rates to six trip purposes namely: work, hospitals, social (relative and friends), markets, religious centres and bank. Trip characteristics examined under the different trip purposes include: trip frequency, trip distance and mode choices (see Nutley, 2005).

\subsubsection{Trip Generation}

The respondents made 1137 trips to six trip purposes within a period of 24 hours. On the average, an elderly made about 3.01 trips per day. Figure 3 shows that in terms of trip purposes, $21.99 \%$ of all trips were social based. Social trips in this study include visiting people, community activities, recreational and all entertainment trips. About $21.37 \%$ of the total trips were hospitals trips. Trips made to banks and worship centres were $15.22 \%$ and $14.95 \%$ respectively. In addition, $13.54 \%$ of total trips were work based trips, while the least trip (12.93\%) was made to markets.

Table 2: Sample characteristics by Gender

\begin{tabular}{|c|c|c|c|}
\hline \multirow[t]{2}{*}{ Variable } & \multirow[t]{2}{*}{ Categories } & \multicolumn{2}{|c|}{ Gender } \\
\hline & & Male in $\%(n=236)$ & Female in $\%(n=142)$ \\
\hline \multirow[t]{4}{*}{ Marital Status } & Single & 0 & 3.52 \\
\hline & Married & 96.61 & 34.51 \\
\hline & Widowed & 2.97 & 59.86 \\
\hline & Divorced & 0.42 & 2.11 \\
\hline \multirow[t]{4}{*}{ Age Group } & 60 to 64 Years & 29.66 & 12.68 \\
\hline & 65 to 69 Years & 19.92 & 41.55 \\
\hline & 70 to 74 Years & 22.46 & 21.13 \\
\hline & Above 75 Years & 27.97 & 24.65 \\
\hline \multirow[t]{5}{*}{ Educational Background } & Informal & 20.34 & 45.77 \\
\hline & Primary & 13.14 & 28.87 \\
\hline & Secondary & 18.64 & 14.08 \\
\hline & University & 29.24 & 11.27 \\
\hline & NCE/Polytechnic Education & 18.64 & 0 \\
\hline \multirow[t]{2}{*}{ Employment Status } & Not Employed & 70.76 & 39.44 \\
\hline & Employed & 29.24 & 60.56 \\
\hline \multirow[t]{4}{*}{ Occupation } & Not Applicable & 70.76 & 39.44 \\
\hline & Farming & 13.98 & 5.63 \\
\hline & Trading & 9.75 & 46.48 \\
\hline & Retired/Pension & 5.51 & 8.45 \\
\hline \multirow[t]{6}{*}{ Monthly Income Range } & None & 70.76 & 39.44 \\
\hline & Below $=\mathrm{N}=10,000$ & 19.92 & 39.44 \\
\hline & $=\mathrm{N}=10,001$ to $=\mathrm{N}=20,000$ & 7.2 & 10.56 \\
\hline & $=\mathrm{N}=20,001$ to $=\mathrm{N}=30,000$ & 2.12 & 9.15 \\
\hline & $=\mathrm{N}=30,001$ to $=\mathrm{N}=40,000$ & 0 & 0.7 \\
\hline & Above $=\mathrm{N}=50,000$ & 0 & 0.7 \\
\hline \multirow[t]{4}{*}{ Income Level } & None & 70.76 & 39.44 \\
\hline & Low Income & 27.12 & 50 \\
\hline & Medium Income & 2.12 & 9.86 \\
\hline & High Income & 0 & 0.7 \\
\hline
\end{tabular}




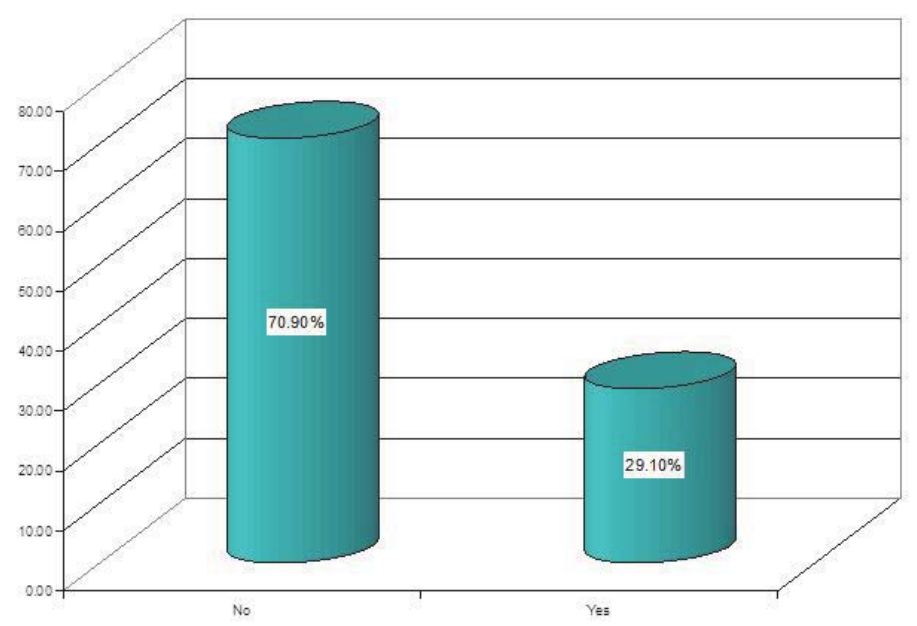

Figure 2: Ownership of means of transport

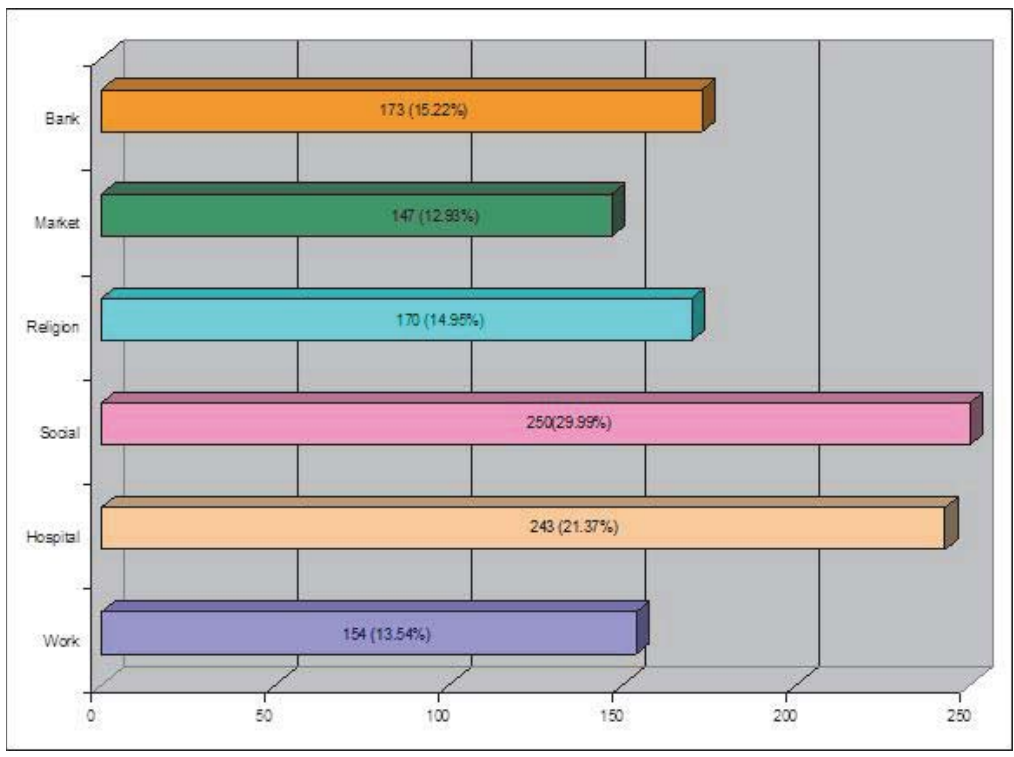

Figure 3: Trip purpose

\subsubsection{Trip Patterns}

Figures $4 \mathrm{a}$ to $4 \mathrm{f}$ show origin and destination patterns of trips to six trips purposes. Owa's Palace zone, constituted the most important origin and destination zone in the study area. Most of the trips including work (13.64\%), social (12.80\%), religious (12.94 \%) and market (12.24\%) trips originated from the zone. Similarly, the zone attracted substantial parts of trips from other zones. This is not strange, as Owa's palace zone is the most central zone in the town. It is also the central business district (CBD) of llesa and also serves as the commercial midpoint of ljesaland.

Other important work trip destination zones as shown in Figure 4a are Bolorunduro (17.53\%) and Oke Ooye (10.39\%). Ayeso (51.44\%) and General hospital zone (22.22\%) served as the most important destination for health trips (Figure 4b). Health trip patterns conform with the distribution of health facilities in the city. There are only two major hospitals owned by the Federal and State government in the study area: Wesley Guild's Hospital, a branch of Obafemi Awolowo University Teaching Hospital, lle-lfe located in Ayeso zone and the Osun State General Hospital located in General hospital zone. In addition, there are sixteen private hospitals and twenty-two primary health centres (PHCs) in the city (Sanni, 2010). The percentage of hospital trips attracted by other zones (Figure $4 \mathrm{~b}$ ) are llaje (4.94\%), Imo (4.94\%), Oke Oye (3.70\%), Owa's Palace (2.88\%), George Botton / Ibala (2.47\%), Irojo (2.47\%), Okesa (1.65\%) and Isokun (1.23\%). 
Social trips to relative, friend, recreation and entertainment locations collectively accounted for $29.99 \%$ of the total trips. Spatial distribution of social trips (Figure 4c) shows the distribution of social trips generated by the zones: Owa's Palace (12.80\%); Ilaje (13.60\%) ; Imo (8.40 percent); Okesa (10.40\%); Irojo (10.40\%); Bolorunduro (5.20\%); General Hospital Area (10.80\%); George Botton/lbala (2.80\%); Oke Ooye (15.60 \%) and Isokun (10.00\%). On the other hand, all zones served as destination zones for social trips (Figure 4c).

Figure $4 \mathrm{~d}$ shows the distribution of religious trips among the eleven zones in llesa. The proportions of trips generated and attracted by the zones are well distributed. In terms of trip generation, General Hospital zone generated $15.88 \%$, while $12.94 \%$ of the trips came from Owa's Palace and Imo zones respectively (Figure 4d). The percentage of religious trips generated by other zones are Ilaje (8.24\%), Okesa (5.88 \%), Irojo (5.88\%), Bolorunduro (2.94 \%), Oke Oye (3.70\%), Ayeso (10\%), George Botton / Ibala (4.71\%), Oke Ooye (11.76\%) and Isokun (8.82\%). In terms of trip destinations, Owa's Palace zone attracted most $(65.88 \%)$ of religious trips, while religious trip to other zones are relatively small.

Market trips in llesa consisted of trips to market places and shopping complex/supermarkets. Field observation revealed that there were nine daily / periodic markets in the city. These markets are located in seven of the zones: Owa's Palace, Ilaje , Imo , Okesa ,Irojo , Ayeso and Isokun zones. In addition, all zones in the study area have varying numbers of supermarkets and shops located along major roads within the city. Owa's palace zone received the highest (87.07\%) volume of market trips. This is expected, Owa's palace zone has the largest and oldest traditional market called Atakunmosa market in llesa, while Irojo zone, the location of Sabo markets, a popular market for the sales of farm produce such as plantain, yam, rice vegetable and kolanuts, attracted 6.80 of market trips. The proportions of market trips generated by each of the zones are shown in Figure 4e.

Banking is a high order function occurring only in important central places where modern commercial transaction has been developed and where opportunities exist for employment (Abiodun, 1971). In the study area, only three zones: Owa's palace, Okesa, and Isokun zones possess this services and their dominance within llesa is overwhelming (Figure 4f). Based on spatial distribution of banks in llesa town, trips to banks by the elderly are directed to the three zones. For instance, Owas' palace zones attracted the highest (71\%) bank trips from all the zones. Okesa zone attracted to its sphere of influence $20.23 \%$ of bank trips from nine zones. Similarly, Isokun attracted $8.67 \%$ of trips to banks from seven zones. In terms of bank trips generation: Ilaje (16.18\%), Imo (15.61\%), Oke Ooye (15.03\%) and Irojo (10.98\%) zones generated the highest trips respectively.

\subsubsection{Trip Frequencies}

Trip frequencies to all trip purposes are shown in Table 3. Occasional trips accounted for more than $51 \%$ of total trip frequency. Hospital (96.71\%) and bank (73.99\%) trips had the largest share of occasional trips. Daily trips accounted for $19.26 \%$ of the total trips. However variations exist in trip frequencies within each of the trip purposes, $86.36 \%$ of work trips and $37.06 \%$ of religious trip were made on daily basis (Table 3 ). The least trip frequencies (8.71\%) and (4.75\%) were made on a fortnightly and weekly basis respectively.

Table 3: Percentage trip frequency

\begin{tabular}{cccccccc}
\hline \multirow{2}{*}{ Trip Characteristics } & \multicolumn{3}{c}{ Trip Purposes (in percent) } & \multicolumn{2}{c}{ Total (in percent) } \\
\hline Daily & Work & Hospital & Social & Religion & Market & Bank & 19.26 \\
Three Times Per Week & 86.36 & 0 & 5.2 & 37.06 & 6.8 & 0 & 4.75 \\
Weekly & 1.95 & 2.06 & 8.8 & 1.76 & 14.29 & 0 & 8.71 \\
Fortnightly & 6.49 & 0.82 & 7.2 & 25.29 & 17.69 & 0 & 15.39 \\
Occasionally & 5.19 & 0.41 & 36 & 6.47 & 13.61 & 26.01 & 51.89 \\
\hline
\end{tabular}




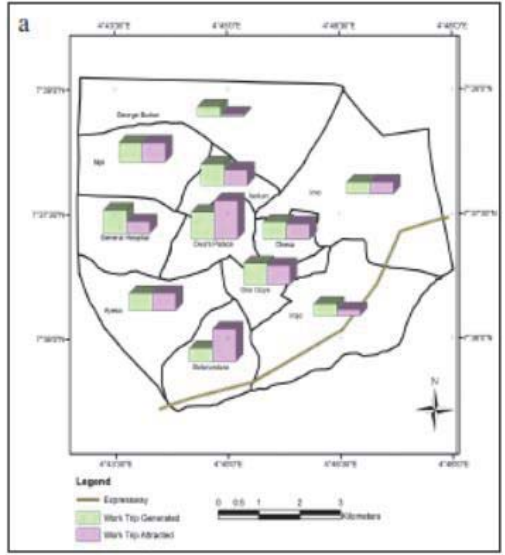

Figure 4a-Work trips

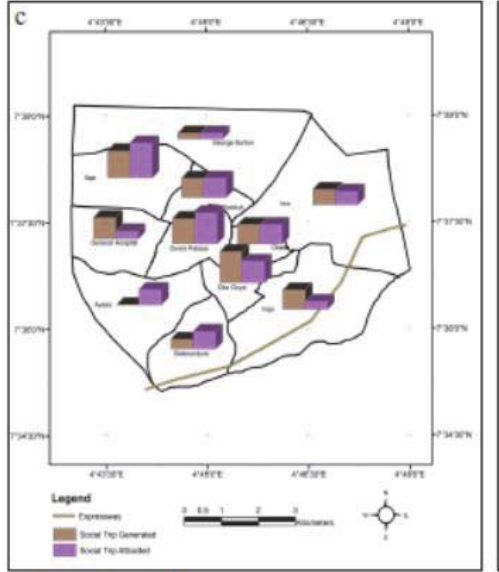

Figure $4 c$.Social trips

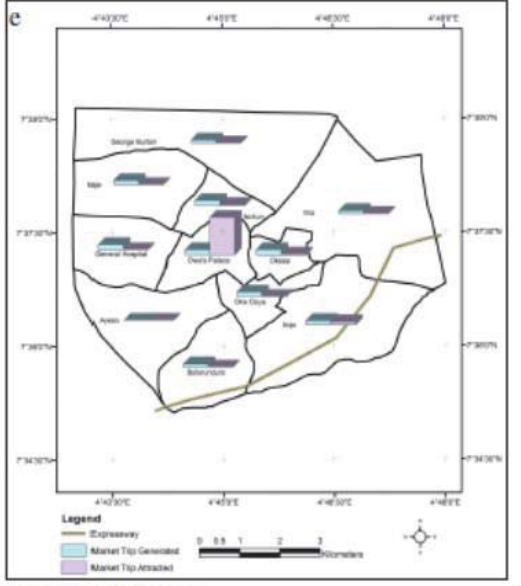

Figure 4e. Market trips

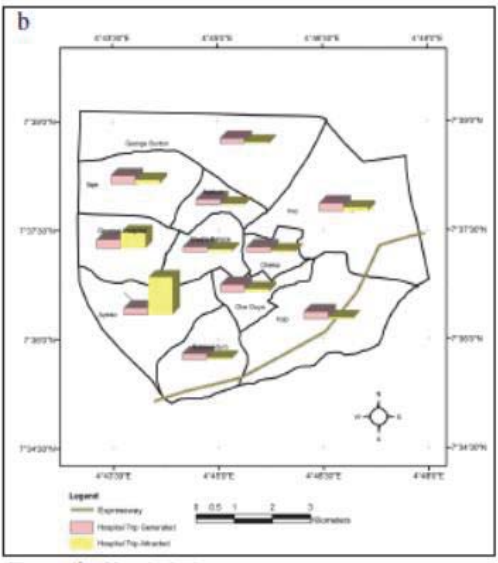

Figure 4b. Hospital trips

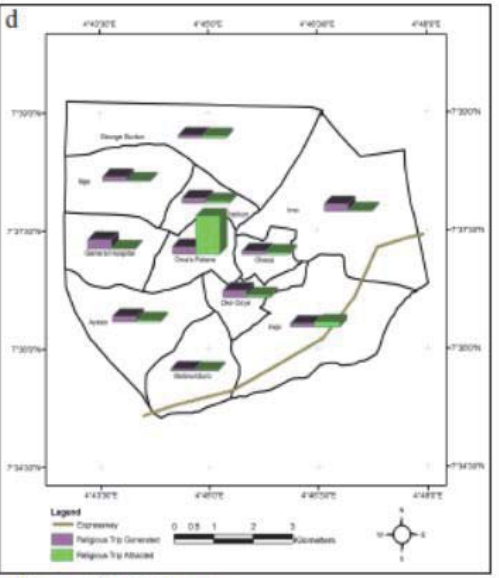

Figure 4d. Religious trips

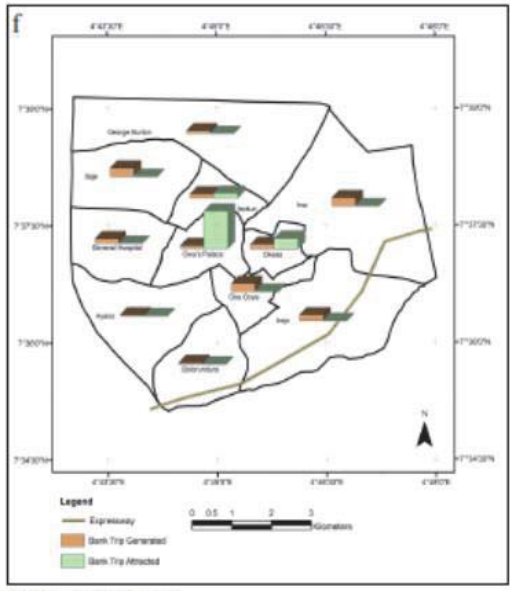

Figure 4f. Bank trips

\subsubsection{Trip Distances}

Traveled distance varies by trip purposes. About $25.59 \%$ of total trips were associated with travel distance of $1 \mathrm{~km}$ and below, while $13.81 \%$ of the elderly traveled a distance of $1 \mathrm{~km}$ to $2 \mathrm{~km}$. About $30.26 \%$ of total trips were associated with travel distance of $3 \mathrm{~km}$ to $4 \mathrm{~km}$. Those who traveled a distance of $2 \mathrm{~km}$ to $3 \mathrm{~km}$ were $18.21 \%$ and about of 30.26 of the aggregate trips is associated with the travel distance of $3 \mathrm{~km}$ to $4 \mathrm{~km}$. Few elderly $(12.14 \%)$ were associated with distance of $4 \mathrm{~km}$ and above (Table 4). 
However, within each of the six trip purposes, wide ranges of travel distances exist. For example, only work trip recorded as high as $25.32 \%$ elderly that were associated with travel distance above $4 \mathrm{~km}$ (Table 4). Trip purpose with high proportion of elderly who traveled between $3 \mathrm{~km}$ to $4 \mathrm{~km}$ are religious (52.35\%), market (43.54\%) and bank (36.99\%). Similarly, in the category of travel distance of $1 \mathrm{~km}$ and below, work trips (25.32\%), hospital (32.1\%) and social (39.6\%) trips had the highest proportion of elderly that travelled distance of $1 \mathrm{~km}$ and below to their trip destinations (Table 5). This is to be expected from trips to work and hospitals, since most of the elderly have their work place located within or short distance away from their residence, while health facilities of different categories are spatially distributed among the zones in the study area.

Table 4: Travel distance for all trip purposes

\begin{tabular}{cccccccc}
\hline \multirow{2}{*}{ Trip Characteristics } & \multicolumn{3}{c}{ Trip Purposes (in percent) } & & \multirow{2}{*}{ Total (in percent) } \\
& Work & Hospital & Social & Religion & Market & Bank & 25.59 \\
Below 1KM & 25.32 & 32.1 & 39.6 & 19.41 & 7.48 & 17.92 & 13.81 \\
1KM To 2KM & 22.73 & 9.88 & 16.4 & 6.47 & 13.61 & 15.03 & 18.21 \\
2KM To 3KM & 11.04 & 21.81 & 15.6 & 10.59 & 27.21 & 23.12 & 30.26 \\
3KM To 4KM & 15.58 & 28.4 & 13.6 & 52.35 & 43.54 & 36.99 & 12.14 \\
Above 4KM & 25.32 & 7.82 & 14.8 & 11.18 & 8.16 & 6.94 & \\
\hline
\end{tabular}

\subsubsection{Trip Mode}

Taxis dominated other modes of transport for the elderly in the city. Taxis accounted for $31.49 \%$ of mode choice to all trips. The second most used mode is walking. As would be expected, walking accounted for about $(28.68 \%)$ of mode choice of the elderly (Table 5). Commercial motorcycle as a mode of transport to all trips was used by $19.61 \%$ of the sampled elderly, while $14.25 \%$ and $5.98 \%$ used personal means of transport and minibuses as mode choice for their trips. The use of minibuses as mode choice by the elderly in llesa is relatively low. This may be attributed to it design which makes embarking and disembarking uncomfortable for the elderly. In addition, the fact that minibuses services are available along few routes, namely from round about at Owa Palace zone's to Osun State College of Education and along brewery road make it unpopular among the elderly who resided in areas not served by minibuses.

Different variations exist in mode choice of the elderly by trip purpose (Figure 5). About $39.61 \%$ and $46.4 \%$ of work and social trips took place by walking, while $6.49 \%$ and $10.8 \%$ of the same trip purposes were made with personal means of transport. Figure 5 also shows the proportions of elderly that traveled by the mode in each of the six trip purposes. Motorcycles appear to be an important mode choice of the elderly. It accounted for $19.48 \%$ of work trips, hospital (13.99\%), social (15.6 5\%), religious (22.35\%) market (17.69\%) and $32.37 \%$ of trips to bank.

Chi square test of association indicated that walking as mode to work place and gender of the elderly are statistically significant $X 2(1, N=154)=5.900, p<0.05$. Similarly, walking to social activity points and gender of the elderly are statistically significant, $X 2(1, N=250)=5.315, p<0.05$, but not statistically significant with age groups, $X 2(3$, $N=250)=5.168, p>0.05$. However, walking to hospital and gender of the elderly are not statistically significant $x 2(1, N$ $=243)=2.049, p>0.05$, but statistically significant with age groups, $X 2(3, N=243)=7.967, p<0.05$

Table 5. Percentage travel mode for all trip purposes

\begin{tabular}{|c|c|c|c|c|c|c|c|}
\hline \multirow{2}{*}{ Trip Characteristics } & \multicolumn{6}{|c|}{ Trip Purpose (in percent) } & \multirow{2}{*}{ Total (in percent) } \\
\hline & Work & Hospital & Social & Religion & Market & Bank & \\
\hline Foot & 39.61 & 29.22 & 46.4 & 16.47 & 21.09 & 10.98 & 28.67 \\
\hline Motorcycle & 19.48 & 13.99 & 15.6 & 22.35 & 17.69 & 32.37 & 19.61 \\
\hline Taxis & 20.78 & 39.51 & 18.4 & 41.18 & 47.62 & 25.43 & 31.49 \\
\hline Mini Bus & 13.64 & 1.23 & 8.8 & 0.59 & 13.61 & 0.58 & 5.98 \\
\hline Personal Car & 6.49 & 16.05 & 10.8 & 19.41 & 0 & 30.64 & 14.25 \\
\hline
\end{tabular}




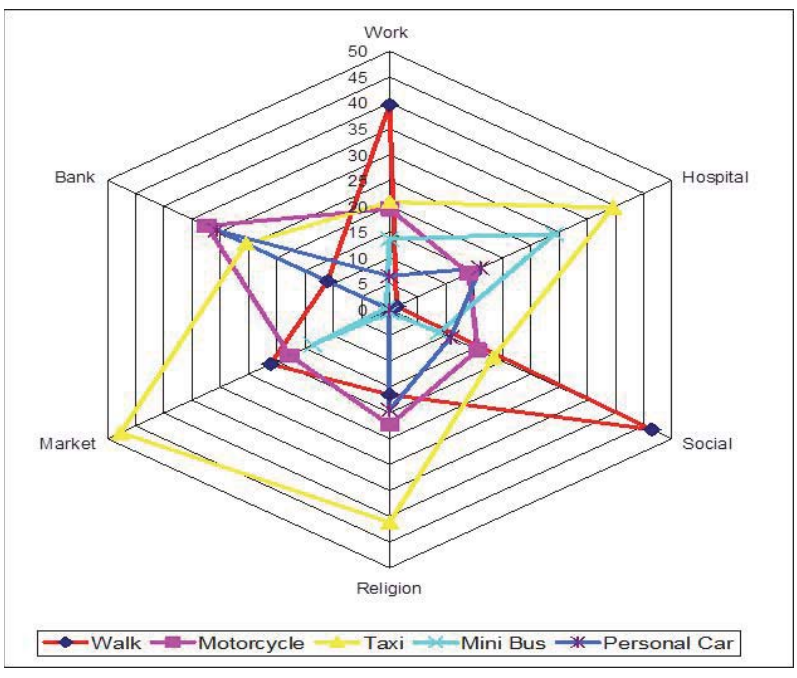

Figure 5. Percentage trip mode for all trip purposes

\subsubsection{Trip Time}

The most common aggregate travel time was fifteen minutes or less. For instance, $59.28 \%$ of the respondents spent fifteen minutes or less to travel to different activities destinations. The second most common travel duration was 15 to 30 minutes (Figure 6). About $14.6 \%$ of the elderly spend between 31 and 45 minutes to travel to their activities destinations. The proportions of the sample that spent 46 to 60 minutes and 61 minutes and above are very small 2.99\%and $3.34 \%$ respectively. There is however, a remarkable similarity in travel time among the six trip purposes. For example, the proportion of elderly trips decreases with in increases in travel time in four of the six trip purposes: work, hospital, religious and bank trips. Trip to markets on other hand increased from $34.01 \%$ for elderly whose travel time was fifteen minutes or less to $59.18 \%$ for elderly that spend between 36 and 45 minutes to travel to market. Thereafter, the proportion decreases with increases in travel time. This trend is rooted in the spatial spread of markets and shopping centres in the city, which necessitate the elderly located in zones without market to spend more time travelling than the elderly in the zones with markets..

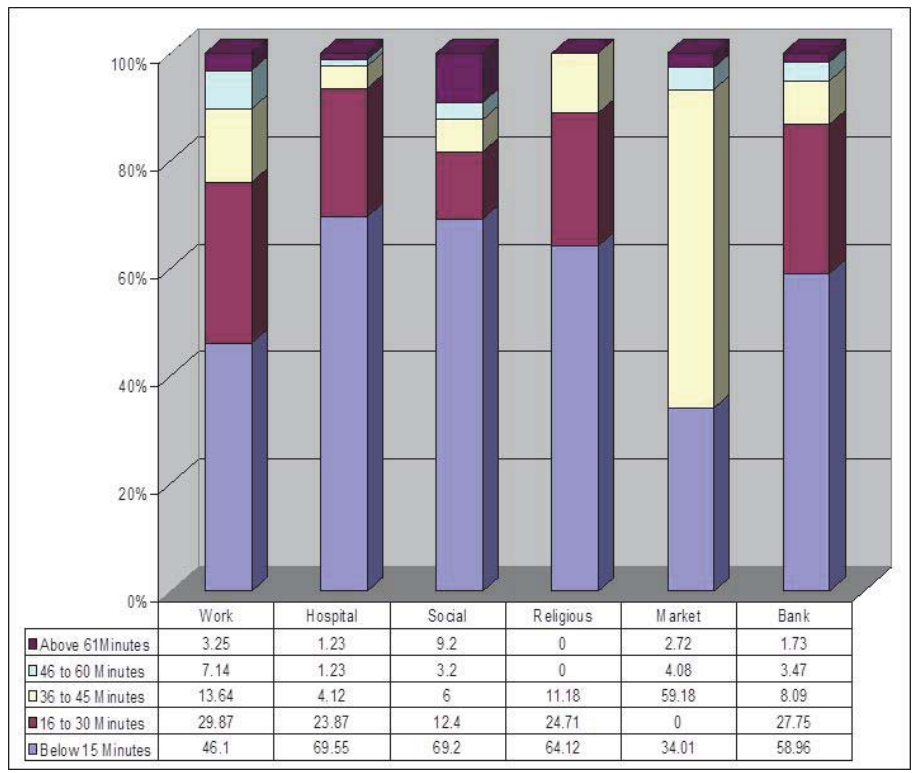

Figure 6: Travel time 


\subsubsection{Trip Cost}

In the study area, the average transport fare charged by commercial taxi and minibus operators from round about, a popular junction located at the front of Owa's Palace, to any part of the city was $=\mathrm{N}=30.00 \mathrm{~K}$ at the time of the survey, while commercial motorcycles are relatively more expensive than commercial taxi and minibuses. Their charges start from $=\mathrm{N}=40.00 \mathrm{~K}$ and upwards depending among others : on distance, number of passengers, loads to transport and time of the day. Table 6 shows the cost of travel to different trip destinations in the city of llesa. The category of the respondents that incurred no transport cost account for $28.76 \%$ of the total trips. Most of the elderly whose main mode is walking belong to this category. Almost equal proportions ( $28.23 \%)$ of the sampled elderly spent $=\mathrm{N}=30$ as transport fare to reach their trip destinations. Some (16.45\%) of the elderly paid $=\mathrm{N}=30$ to $=\mathrm{N}=40$ as transport fees to their trip zones. The proportions of the elderly who paid $=\mathrm{N}=40$ to $=\mathrm{N}=50$ to reach their destinations are insignificant $(9.67 \%)$, while those who paid above $=\mathrm{N}=50.00 \mathrm{~K}$ as transport fare to their destinations were 16.89 percent.

Table 6: Trip Cost

\begin{tabular}{cccccccc}
\hline \multirow{2}{*}{ Travel Cost } & \multicolumn{9}{c}{ Trip Purpose (in percentage) } & \multirow{2}{*}{ Total (in percent) } \\
& Work & Hospital & Social & Religion & Market & Bank & \\
\hline None & 18.18 & 29.63 & 43.2 & 24.12 & 34.01 & 16.18 & 28.76 \\
$=\mathrm{N}=20$ to $=\mathrm{N}=30$ & 31.17 & 25.10 & 17.20 & 22.94 & 59.18 & 24.86 & 28.23 \\
$=\mathrm{N}=30$ to $=\mathrm{N}=40$ & 18.83 & 22.63 & 10.40 & 17.06 & 4.08 & 24.28 & 16.45 \\
$=\mathrm{N}=40$ to $=\mathrm{N}=50$ & 5.19 & 7.82 & 4.80 & 23.53 & 2.72 & 15.61 & 9.67 \\
Above $=\mathrm{N}=50$ & 26.62 & 14.81 & 24.40 & 12.35 & 0.00 & 19.07 & 16.89 \\
\hline
\end{tabular}

\subsection{Logistic Regression Model}

The result of Logistic Regression Analysis contained three sequential blocks: model (0) without predictors, model (1) with socio-demographic attributes of the elderly as the predictors and model (2) with trip attributes as the predictors. The next two sections discuss the result of the models with respect to walk as mode choice to work places (section 5.3.1) and other non work trips purposes (section 5.3.2).

\subsubsection{Work Trip Model Results}

The results of logistic regression analysis of walk as mode of transport to work as shown in Table 7 implies that the choice of mode is influence by both socio-economic and trip characteristics. Three of the socio-economic independent variables in the model 1 (gender, education and monthly income) were statistically significant at $p<0.05$. According to the model, the log of the odds of an elderly walking to places of work were negatively related to gender, educational status and income $(p<0.05$; Table 7$)$. In other words, male elderly were more likely to walk than female because male were coded (1) and female (0). In fact, the odd of a male walking to work place is 0.424 . However, model (1) lack significant difference from the model ( 0 ) containing only constant as revealed by the goodness-of-fit test statistic, $X^{2}=4.175$, df $=8$, $p>0.05$. This implies that the model is a good fit of the data, suggesting that walking as mode choice of the elderly to work places is influenced by socio-economic variables. The amount of variations in the dependent variable explained by model (1) is relatively low. About $14.11 \%$ (Cox \& Snell $\mathrm{R}^{2}$ ) or $19.10 \%$ (Nagelkerke $\mathrm{R}^{2}$ ) of the variability is explained by the socio-economic variables used in the model.

In Model 2, the results indicated that walking as mode of travel by the elderly to work place is negatively related to travel distance and transport cost $(p<0.05)$. The Hosmer-Lemeshow chi-square value is $X^{2}=14.686, \mathrm{df}=8, p>0.05$. Model (2) indicates an improvement in the ability of the additional variables, trip characteristics, included in model (2) to influence the choice of walking as mode choice by the elderly.

\subsubsection{Other Trips Model Results}

Table 8 shows the results of logistic analyses of the factors associated with walking as mode choice to four other trip purpose destinations: hospital, social, religious and bank. Details of model (2) estimates are include in the table, summaries of Model (1) such as -2 Log likelihood, Cox \& Snell R Square, Nagelkerke R Square, Hosmer-Lemeshow Chisquare and overall percentage predicted by model (1) are shown for hospital, social, religious and bank trips. The log of 
the odds of an elderly walking to trips destinations as shown in Table 8 were negatively related to gender, travel distance and cost of the elderly with respect to hospital, social and religious trips $(p<0.05)$. The amount of variation in the dependent variable explained by model (2) is relatively high especially with respect to hospital, social and religious trips. For instance, about $54.4 \%\left(C o x \&\right.$ Snell $R^{2}$ ) or $77.8 \%$ (Nagelkerke $R^{2}$ ) of the variability in trip to hospital is explained by socio-economic and trip variables in model (2). Similar trend is shown in Table 8 with respect to social and religious trips, while the amount of variation in the dependent variable explained by model (2) is relatively low for trip to bank. About $17.9 \%$ (Cox \& Snell $\mathrm{R}^{2}$ ) or $17.9 \%$ (Nagelkerke $\mathrm{R}^{2}$ ) of the variability is explained by the variables used in model (2).

Table 7. Logistic regression model of trip to work place. (Dependent variable: mode choice to work ( $1=$ walk, $0=$ others).

\begin{tabular}{|c|c|c|c|c|c|c|c|c|c|}
\hline \multirow{3}{*}{ Independent Variables } & \multicolumn{9}{|c|}{ Logistic Regression Model of Trip to Work Place - Walk } \\
\hline & \multicolumn{3}{|c|}{ Model (0) Constant Only } & \multicolumn{3}{|c|}{ Model (1): Socio-economic attributes } & \multicolumn{3}{|c|}{ Model (2): Trip attributes } \\
\hline & $\mathrm{B}$ & Sig. & $\operatorname{Exp}(B)$ & $\mathrm{B}$ & Sig. & $\operatorname{Exp}(B)$ & $\mathrm{B}$ & Sig. & $\operatorname{Exp}(\mathrm{B})$ \\
\hline Constant & -0.422 & 0.01 & 0.656 & 1.846 & 0.026 & 6.335 & 7.562 & 0.000 & 1924.19 \\
\hline Gender (Male $=1$, Female $=0$ ) & & & & -0.858 & 0.019 & 0.424 & -1.367 & 0.037 & 0.255 \\
\hline Marital Status & & & & -0.04 & 0.81 & 0.961 & 0.43 & 0.097 & 1.537 \\
\hline Age Group & & & & 0.012 & 0.946 & 1.012 & 0.248 & 0.417 & 1.282 \\
\hline Educational Background & & & & -0.394 & 0.033 & 0.674 & -0.737 & 0.014 & 0.479 \\
\hline Income Range & & & & -0.789 & 0.006 & 0.454 & -0.222 & 0.612 & 0.801 \\
\hline Transport Means $($ Yes $=1, \mathrm{No}=0)$ & & & & & & & -1.136 & 0.185 & 0.321 \\
\hline Trip Frequency & & & & & & & 0.22 & 0.618 & 1.247 \\
\hline Travel Distance & & & & & & & -1.367 & 0.000 & 0.255 \\
\hline Travel Time & & & & & & & 0.746 & 0.037 & 2.108 \\
\hline Travel Cost & & & & & & & -1.135 & 0.000 & 0.321 \\
\hline-2 Log likelihood & & & & & 183.354 & & & 85.592 & \\
\hline Cox \& Snell R Square & & & & & 0.141 & & & 0.545 & \\
\hline Nagelkerke R Square & & & & & 0.191 & & & 0.737 & \\
\hline Hosmer-Lemeshow Chi-square & & & & & 4.175 & & & 14.686 & \\
\hline Df & & & & & 8 & & & 8 & \\
\hline Sig. & & & & & 0.841 & & & 0.066 & \\
\hline Overall Percentage Predicted & & 60.400 & & & 66.9 & & & 89.6 & \\
\hline
\end{tabular}

Table 8. Logistic regression model of other trips (Dependent variable: mode choice to trip destinations $(1=$ walk, $0=$ others).

\begin{tabular}{|c|c|c|c|c|c|c|c|c|c|c|c|c|}
\hline \multirow{2}{*}{ Independent Variables } & \multicolumn{3}{|c|}{ Hospital Trip } & \multicolumn{3}{|c|}{ Social Trip } & \multicolumn{3}{|c|}{ Religious Trip } & \multicolumn{3}{|c|}{ Bank Trip } \\
\hline & B & Sig. & $\operatorname{Exp}(B)$ & $\mathrm{B}$ & Sig. & $\operatorname{Exp}(B)$ & $\mathrm{B}$ & Sig. & $\operatorname{Exp}(B)$ & $\mathrm{B}$ & Sig. & $\operatorname{Exp}(B)$ \\
\hline Constant & 5.373 & 0.012 & 215.60 & 11.051 & 0.000 & 630.2 & 7.624 & 0.039 & 2047.48 & 39.685 & 0.999 & 17.186 \\
\hline Gender (Male $=1$, Female $=0$ ) & -0.75 & 0.29 & 0.473 & -2.053 & 0.013 & 0.128 & -2.885 & 0.007 & 0.056 & -0.824 & 0.255 & 0.439 \\
\hline Marital Status & -0.128 & 0.627 & 0.88 & 0.41 & 0.336 & 1.506 & -0.053 & 0.894 & 0.949 & 0.432 & 0.250 & 1.541 \\
\hline Age Group & 0.169 & 0.523 & 1.184 & -0.095 & 0.746 & 0.909 & 0.548 & 0.200 & 1.729 & -0.635 & 0.031 & 0.530 \\
\hline Educational Background & -0.497 & 0.012 & 0.609 & -0.47 & 0.048 & 0.625 & -0.522 & 0.180 & 0.593 & -0.196 & 0.402 & 0.822 \\
\hline Income Range & -0.39 & 0.18 & 0.677 & 0.064 & 0.843 & 1.066 & 0.237 & 0.599 & 1.268 & -0.106 & 0.710 & 0.900 \\
\hline Transport Means (Yes =1, No = 0) & 0.444 & 0.477 & 1.559 & -1.511 & 0.049 & 0.221 & -1.491 & 0.182 & 0.225 & 0.212 & 0.744 & 1.236 \\
\hline Trip Frequency & 0.778 & 0.381 & 2.177 & -0.285 & 0.409 & 0.752 & -0.170 & 0.650 & 0.843 & -18.965 & 0.999 & 0.000 \\
\hline Travel Distance & -1.248 & 0.000 & 0.287 & -2.057 & 0.000 & 0.128 & -1.412 & 0.001 & 0.244 & -0.386 & 0.068 & 0.680 \\
\hline Travel Time & 0.526 & 0.202 & 1.692 & 1.334 & 0.003 & 3.796 & 0.442 & 0.464 & 1.555 & 0.708 & 0.024 & 2.031 \\
\hline Travel Cost & -1.096 & 0.000 & 0.334 & -1.526 & 0.000 & 0.217 & -1.460 & 0.001 & 0.232 & -0.587 & 0.004 & 0.556 \\
\hline
\end{tabular}

Block (0) Constant only

Overall Percentage Predicted

Block (1): Socio-economic attributes

-2 Log likelihood

Cox \& Snell R Square

Nagelkerke R Square

Hosmer-Lemeshow Chi-square
71.2

250.69

0.156

0.223

1.602
53.6

327.22

0.07

0.093

15.323
83.5

89.000

103.36

0.09

0.181

6.731 


\begin{tabular}{lcccc} 
ISSN 2039-2117 (online) & Mediterranean Journal of Social Sciences & Vol 6 No 3 S2 \\
ISSN 2039-9340 (print) & \multicolumn{2}{c}{ MCSER Publishing, Rome-Italy } & 2015 \\
& \multicolumn{2}{c}{} & 8 & 8 \\
df & 8 & 8 & 0.316 & 0.566 \\
Sig. & 0.991 & 0.053 & 95.9 & 89.6 \\
Overall Percentage Predicted & 74.5 & 57.6 & & 85.634 \\
& & & 42.423 & 0.179 \\
Block (2): Trip attributes & 101.106 & 78.585 & 0.475 & 0.179 \\
-2 Log likelihood & 0.544 & 0.656 & 0.804 & 11.340 \\
Cox \& Snell R Square & 0.778 & 0.876 & 9.324 & 8 \\
Nagelkerke R Square & 121.641 & 1.712 & 8 & 0.183 \\
Hosmer-Lemeshow Chi-square & 8 & 8 & 0.316 & 93.1 \\
df & 0.000 & 0.989 & 95.9 & \\
Sig. & 94.70 & 94.000 & & \\
Overall Percentage Predicted & & & \\
\hline
\end{tabular}

\section{Discussion}

This study was conducted to examine the intra-urban trip patterns and mode choice of the elderly in a medium size city in Southwestern Nigeria

This study found that socio-economic characteristics and employment status of the elderly in the study area are consistent with previous studies in Nigeria (NPC, 2003; Ipingbemi, 2010). The high proportion of the elderly involved in employment lends credence to the level of poverty among the elderly in the country. The implications of this is that the elderly who are engaged in labour force are more exposed to mobility constraints, as they are generate more trips than retired elderly.

The study showed that ownership motorized transport means was very low among the urban elderly. This is in contrast with the findings in advanced countries where more than 75\% of people over 65 years have some access to personal car (Rosenbloom and Waldorf, 2001; Stamatiadis et al. 1996). This finding implies that most of the elderly in llesa are likely to dependent on the commercial transportation systems.

The study further showed that taxis and walking are the dominant main modes of travel among the elderly. The mode split among the elderly in llesa is similar to that reported for many other African cities (Bryceson et al., 2003; Ipingbemi 2010).

In terms of trip generation, the average trips of 3.01 trips generated per day by an elderly is about the same as 3.4 trips per day reported by Rosenbloom and Stahl (2002), for countries in North America and Europe.

Short distance travel accounted for substantial travel distance by the elderly. The dominance trips within $1 \mathrm{~km}$ of respondent's place of abode, especially with respect to work, hospital and social trips, show that majority of the elderly are short distance trip makers (see Rietveld, 2000). The study also revealed that trips to religious, market and banking venues took place over a distance of $3 \mathrm{~km}$ to $4 \mathrm{~km}$.

The use of taxis as travel mode dominated other travel modes to all trip destinations. This is in line with the situation in advanced countries where the use of walking as a travel mode has declined absolutely among the elderly (Rosenbloom and Morris, 1998). The significance of walking as mode choice of the elderly in the study area is also revealed. It accounted for the second most used mode of travel. The findings of Ipingbemi (2010) in Ibadan, Nigeria strongly support the relevant of taxis and walking as mode choices of the elderly in llesa.

The study did no validate travel time as influencing the choice of walk as mode of transport. However, distance and transport cost, were shown by this study as strong determinants of walking as model choice.

The study indicates that there exist differences in trip distribution among the eleven zones. In terms of trip attraction, Owa' Palace zone attracted significant proportion of the total trips from other zones especially with respect to trips to work places, market, religious centres, social venues and banks while Ayeso and General Hospital zones constituted the focal points for health trip destinations. The implication of this finding is that trip pattern of the elderly in the study area is highly influence by land uses.

\section{Implications and Conclusion}

The importance of this research is that it has described in detail the intra-urban trip pattern and characteristics of the elderly in a medium sized in Southwerstern , Nigeria

Certain policy implications emerge from the study. First, since most elderly visit destinations at distances of less than $1 \mathrm{~km}$, roads within the city that serves as link between trip origins and destinations should expanded to includepedestrian walkways and safety measures such as zebra crossing. Second, since Owa palace's zone serves as 
the traditional / central business district of the city, access roads from the zone to other zones need to be improve to facilitate movement to and from other zones.

Another important policy area for consideration is the area of the preferred mode of travel (taxis and walking). The Local and the State governments should assist commercial transport operators in the city with funding to purchase new vehicles to be used as taxis in the city. Mobility and safety of the elderly will be enhanced, if the state government could make the city conducive for walking. To this end, government should establish policies to encourage walking to places of short distances. In addition, bus stops with standard facilities should be constructed at strategic location in the city and be made mandatory for all transport operators in the city to use them.

The government at the Federal level should develop transport policies aimed at improving mobility of the elderly in the country. A national policy on transportation with care for mobility of the elderly will influence the formulation of similar policies at State and Local government levels. The effective implementation of all these strategies at Local, State and Federal levels however, requires further studies of the travel behaviour and transportation expectations of the elderly in the country.

\section{References}

Abiodun, J.O, 1971. Service Centres and Consumer Behaviour within the Nigerian Cocoa. Geografiska Annaler. Series B, Human Geography, 53, (2),78-93

Adebowale, S. A., Atte, O., Ayeni, O., 2012. Elderly Well-being in a Rural community in North Central Nigeria, sub-Saharan African. Public Health Research, 2(4), 92 -101.

Adetunji, M. A., 2013. Gender Travel Behaviour and Women Mobility Constraints in llesa, Nigeria. International Journal for Traffic and Transport Engineering, 3(2), 220 - 229.

Ajomale, O., 2007. Country report: Ageing in Nigeria - current state, social and economic implications. International sociological association (ISA). Research committee (RC11) on the Sociology of Ageing: Oxford Institute of Ageing

Banister , D., Bowling, A., 2004. Quality of life for the elderly: the transport dimension. Transport Policy, 11, 105-115.

Bryceson, D.F., Mbara, T.C., Maunder, D. 2003. Livelihoods, daily mobility and poverty in sub-Saharan Africa. Transport Reviews, 23 (2), 177-196.

Engels, B., Liu, G., 2011. Social exclusion, location and transport disadvantage amongst non-driving seniors in a Melbourne municipality, Australia. Journal of Transport Geography, 19, 984 - 996.

Engels, B., Liu, Gang-Jun, 2013. Ageing in Place: The Out-of-Home Travel Patterns of Seniors in Victoria and its Policy Implications, Urban Policy and Research, 31:2, 168-189, DOI: 10.1080/08111146.2012.737316

Golob, T., Hensher, D., 2007. The trip chaining activity of Sydney residents: a crosssection assessment by age group with a focus on seniors. Journal of Transport Geography, 15, 298-312.

Hjorthol, R. J., Levin, A.L., Sirén, A., 2010. Mobility in different generations of older Persons. The development of daily travel in different cohorts in Denmark, Norway and Sweden. Journal of Transport Geography , 18, 624-633.

$\mathrm{Hu}, \mathrm{X}$., Wang, J., Wang, L. 2013. Understanding the travel behavior of elderly people in the developing country: a case study of Changchun, China, Procedia - Social and Behavioral Sciences 96, $873-880$

Ipingbemi, O., 2010. Travel characteristics and mobility constraints of the elderly in Ibadan, Nigeria. Journal of Transport Geography, 18 (2), 285-291.

Kim, S., Ulfarsson, G. F., 2004. Travel Mode Choice of the Elderly: Effects of Personal, Household, Neighborhood and Trip Characteristics. Transportation Research Board, 1894, 117-126

Larsen, K., Gilliland, J., Hess, P.M., 2012. Route-Based Analysis to Capture the Environmental Influences on a Child's Mode of Travel between Home and School. Annals of the Association of American Geographers 102(6), 1348-1365,

Lemeshow, S., Hosmer, D. W., 1982. A review of goodness of fit statistics for use in the development of logistic regression models. American Journal of Epidemiology 115, 92-106.

Metz, D. H., 2000. Mobility of older people and their quality of life. Transport Policy,7, 149-152.

Metz, D., 2003. Transport policy for an ageing population, Transport Reviews: A Transnational Trans disciplinary Journal, 23(4), 375386.

National Population Commission of Nigeria (2006). Population distribution by sex ,state, Igas and senatorial district Retrieved from http://www.population.gov.ng/index.php/publications/140-population-distribution-by-sex-state-lgas-and-senatorial-district-2006census-priority-tables-vol-3> National Population Commission, 2003. The elderly, Nigeria population census 1991

Analysis., Volume 3, Abuja - Nigeria. Retrieved from <http://www.population.gov.ng/index.php/publications/143-elderly>

Nagelkerke, N. J. D., 1991. A note on general definition of the coefficient of determination. Biometrika 78:691-92

Nutley, S., 2005. Monitoring rural travel behaviour: a longitudinal study in Northern Ireland 1979-2001. Journal of Transport Geography $13,247-263$

Olawole, M.O., \& Aloba, O. (2014). Mobility characteristics of the elderly and their associated level of satisfaction with transport services in Osogbo, Southwestern Nigeria Transport Policy, 35, 105-116, DOI information: 10.1016/j.tranpol.2014.05.018 http://authors. elsevier.com/sd/article/S0967070X14001176 
Olawole, M.O., 2012. Accessibility to Lagos bus rapid transit (BRT LITE) bus stops: An empirical study. Paper presented at the International Conference on the role of urban mobility in (re)shaping cities -CODATU XV 22 to 25 October Addis Ababa (Ethiopia) Retrieved from http://www.codatu.org/wp-content/uploads/M.O.-Olawole-ARTICLE-Codatu-XV-2012-EN.pdf>

Páez, A., Scott, D., Potoglou, D., Kanaroglou, P., Newbold, K., 2006. A mixed ordered probit analysis of elderly trip generation in the Hamilton CMA. Paper presented at the 11 th International Conference on Travel Behaviour Research, Kyoto.

Rietveld, P., 2000. Non-motorised modes in transport systems: a multimodal chain perspective for the Netherlands, Transportation Research Part D: Transport and Environment 5 (1), 31-36.

Porter, G., Tewodros, A., Bifandimu,F, Gorman, M., Heslop, A., Sibale, E., Awadh, A., Kiswaga, L. (2013). Transport and mobility constraints in an aging population: health and livelihood implications in rural Tanzania. Journal of Transport Geography $30161-$ 169

Rosenbloom, S., Morris, J., 1998. The travel patterns of older Australians in an international context: Policy implications and options. Transportation Research Record 1617, pp. 91

Rosenbloom, S., Waldorf, B., 2001. Older travelers: Does place or race make a difference? Transportation Research E-Circular E-C026: Personal Travel: The Long and Short of It, TRB, National Research Council, Washington D.C., 2001, pp. 103-120.

Rosenbloom, S., Stahl, A., 2002. Automobility among the elderly. The convergence of environmental, safety, mobility and community design issues EJTIR, 2, (3 \& 4 ), 197-213.

Rosenbloom, S.,2004. Mobility of the elderly: Good news and bad news. In Transportation in an ageing society: A decade of experience, Conference Proceedings 27 (pp. 3-21). Washington, DC: Transportation Research Board of the National Academies.

Sanni, L.,2010. Distribution Pattern of Healthcare Facilities in Osun State, Nigeria . Ethiopian Journal of Environmental Studies and Management, 3(2), $65-76$

Schmöcker, J., Quddus, M., Noland, R., Bell, M.,2008. Mode choice of older and disabled people: a case study of shopping trips in London. Journal of Transport Geography 16, 257-267.

Stamatiadis, N., Leinback, T., Watkins, J., 1996. Travel among non-urban elderly. Transportation Quarterly, 50 (3).

Stern, S., 1993. A disaggregate discrete choice model of transportation demand by elderly and disabled people in rural Virginia. Transportation Research Part A, 27 (4), 315-327.

Togonu-Bickersteth, F.(2014). Ageing is not an emergency: Preparing for the new realities of ageing in Nigeria. Inaugural lectures series 226, Obafemi Awolowo University lle-Ife, Nigeria. p.123

United Nations, 2004. Policy responses to population decline and ageing, Population Bulletin of the United Nations.

Van den Berg, P., Arentze,T. Timmermans, T. 2011. Estimating social travel demand of senior citizens in the Netherlands. Journal of Transport Geography, 19, 323-331

Velkoff, V.A., Kowal, P.R. 2006. Ageing in sub-Saharan Africa: The changing demography of the region. In B. Cohen, \& J. Menken (Eds.) Ageing in sub-Saharan Africa: Recommendations for Furthering Research . National Academy of Sciences. Pp 55 - 91. Retrieved from http://www.nap.edu/catalog/11708.html 